\title{
PENYULUHAN INDUSTRI KREATIF DAN HOMESTAY DI DESA WISATA PAKUALAM KECAMATAN DARMARAJA SUMEDANG
}

\author{
Endah Djuwendah, Eliana Wulandari dan Erna Rachmawati \\ Prodi Agribisnis Fakultas Pertanian Universitas Padjadjaran \\ E-mail: endah.djuwendah@unpad.ac.id
}

\begin{abstract}
ABSTRAK. Desa wisata merupakan salah satu produk wisata alternatifyang diharapkan dapat memberikan dorongan bagi pembangunan perdesaan yang berkelanjutan dalam upaya membuka lapangan pekerjaan, menjaga kelestarian budaya lokal sekaligus mempertahankan kelestarian lingkungan. Pemberdayaan masyarakat melalui industri kreatif berbasis sumberdaya lokal dan pengemasan homesatay menjadi salah satu faktor dalam menunjang pengembangan desa wisata. Tujuan dari kegiatan Pengabdian pada masyarakat ini adalah untuk meningkatkan partisipasi masyarakat dalam pengembangan desa wisata. Metode yang dilakukan adalah kualitatif deskriptif melalui model pendekatan Focus Group Dsicution (FGD) dan teknologi transfer (TT). Guna mencapai tujuan tersebut kegiatan yang dilakukan adalah penyuluhan potensi dan peluang ekonomi kreatif penunjang wisata serta penyuluhan dan pendampingan pondok wisata (homestay). Hasil kegiatan menunjukkan adanya peningkatan pengetahuan dan minat masyarakat dalam memanfaatkan sumberdaya lokal melalui industri kreatif serta penyediaan homestay dalam menunjang aktifitas desa wisata. Terdapat kendala pengembangan industri kreatif di desa wisata Pakualam yaitu permodalan, keterampilan SDM, teknologi produksi, pemasaran dan dukungan pemerintah. Sedangkan penyediaan homestay memiliki kendala dalam hal keterbatasan ruangan, fasilitas pendukung yang kurang lengkap, serta kurangnya keterampilan dalam pengelolaan homestay. Faktor pendorong keberhasilan industri kreatif dan homestay adalah terdapatnya dukungan dari aparat desa, partisipasi aktif warga masyarakat yang dilatar belakangi oleh motivasi kuat untuk bertahan hidup pasca pengenangan waduk Jatigede dan peluang semakin berkembangnya wisata di kawasan waduk Jatigede.
\end{abstract}

Kata Kunci: industri kreatif; sumberdaya lokal; homestay; dewa wisata

\begin{abstract}
Tourism village is one of the alternative tourism products which is expected to encourage sustainable rural development to open jobs, keep local culture while maintaining environmental sustainability. Community empowerment through creative industries based on local resources and packaging homestay is one factor in supporting the development of tourism villages. The purpose of this community service activity is to increase community participation in the development of tourism villages. The method used is descriptive qualitative through the Focus Group Discussion (FGD) and transfer technology models. In order to achieve these objectives, the activities carried out are counseling of potential and creative economic opportunities to support tourism as well as counseling and mentoring of cottage (homestay). The results of the activity showed an increase in the knowledge and interest of the community in utilizing local resources through the creative industry and the provision of homestays in supporting the activities of tourist villages. There are obstacles to the development of creative industries in the tourist village of Pakualam, namely capital, HR skills, production technology, marketing and government support. While the provision of homestay has constraints in terms of limited space, incomplete supporting facilities, and lack of skills in managing homestays. The driving factor for the success of the creative industry and homestay is the presence of support from village officials, active participation of community members encouraged by a strong motivation to survive after the flooding of the Jatigede dam and the opportunity for increasingly developing tourism in the Jatigede reservoir area.
\end{abstract}

Key words: Creative industry; local resources; homestay; tourism village

\section{PENDAHULUAN}

Waduk Jatigede merupakan salah satu waduk multiguna yang dibangun dengan tujuan untuk: (1) pengairan lahan pertanian seluas 90.000 ha sawah guna meningkatkan produksi padi di utara Indramayu, Majalengka dan Cirebon, (2) penyedia air bersih untuk Kabupaten Sumedang, Cirebon, Indramayu Majalengka dan kawasan Balongan dengan kapasitas 3.500 liter/detik, (3) pengendali banjir saat musim hujan,(4) pembangkit tenaga listrik PLTA dengan kapasitas 110 megawatt, dan (5) sebagai obyek pariwisata (Djuwendah, dkk, 2017)

Semenjak pertama kali digenangi pada tanggal 31 Agustus 2015, potensi pariwisata di kawasan waduk Jatigede mulai terlihat. Seiring dengan semakin tingginya genangan air Waduk, banyak wisatawan yang berdatangan terutama pada hari-hari libur. Peluang pengembangan wisata di waduk Jatigede banyak dimanfaatkan oleh warga sekitar genangan sehingga muncul beberapa obyek wisata di berbagai desa. Saat ini sudah ada empat rintisan desa wisata di kawasan waduk Jatigede yaitu Desa Pakualam dan Karangpakuan di Kecamatan Darmaraja dan Desa Cijeungjing dan Jemah di Kecamatan Jatigede.

Desa wisata merupakan salah satu bentuk penerapan pembangunan pariwisata berbasis masyarakat dan berkelanjutan. Menurut Hadiwijoyo (2018), desa wisata adalah suatu kawasan perdesaan yang menawarkan keseluruhan suasana yang mencerminkan keaslian perdesaan baik dari kehidupan sosial ekonomi, sosial budaya, adat istiadat, keseharian, memiliki arsitektur bangunan dan struktur tata ruang desa yang khas, atau kegiatan perekonomian yang unik dan menarik serta mempunyai potensi untuk dikembangkannya berbagai komponen kepariwisataan, misalnya: atraksi, akomodasi, makananminuman, dan kebutuhan wisata lainnya.

Pengembangan desa wisata dapat diartikan sebagai usaha untuk melengkapi dan meningkatkan fasilitas wisata guna memenuhi kebutuhan wisatawan. Hal yang harus 
menjadi perhatian dalam pengembangan desa wisata yakni bagaimana masyarakat bisa didorong dan dikembangkan secara berkesinambungan, sehingga potensi yang dimiliki desa dan masyarakat dapat dikembangkan secara optimal. Melalui penggalian potensi desa dan masyarakat secara berkesinambungan maka pengembangan desa wisata dapat berdampak maksimal bagi kesejahteraan petani dan masyarakat desa.

Salah satu kegiatan yang dapat meningkatkan kapasitas masyarakat di desa wisata adalah usaha industri kreatif. desa wisata dan industri kreatif erat kaitannya dan saling bersinergi dimana implementasi rill dari keduanya saling berpengaruh dalam menciptakan daya saing yang komprehensif. Berkembangnya desa wisata akan menjadi daya tarik bagi wisatawan sehingga akan mendukung industri kreatif yang ada di daerah sekitarnya dan sebaliknya industri kreatif akan mendorong pengembangan desa wisata.

Simatupang (2009), menyatakan industri kreatif sebagai kegiatan industri yang mengandalkan talenta, keterampilan dan kreativitas yang merupakan eleman dasar setiap individu. Unsur utama industri kreatif adalah kreativitas, keahlian dan talenta yang berpotensi meningkatkan kesejahteraan melalui penawaran kreasi intelektual. Meskipun industri kreatif dan pariwisata memiliki kelompok usaha masing-masing namun di lapangan dapat dilihat adanya kekuatan yang saling mendukung dan memperkuat fungsinya satu dengan lain. Produk-produk industri kreatif selalu tampil dengan ciri khas dan keunikan tersendiri sehingga mampu menciptakan citra sebuah kota dan menarik wisatawan, sehingga melalui peran industri kreatif dapat dikembangkan sebuah pariwisata yang mampu memberikan pengalaman dan pembelajaran bagi wisatawan.

Desa Pakualam merupakan salah satu rintisan desa wisata yang terletak di Kecamatan Darmaraja Kabupaten Sumedang. Desa ini memiliki potensi yang sangat beragam yang dapat dijadikan modal dalam mengembangkan desa wisata. Kondisi lingkungan pedesaan yang alamiah dengan panorama alam yang indah berbatasan langsung dengan genangan air waduk Jatigede. Berbagai potensi yang dimiliki desa Pakualam diantaranya terdapat hutan konservasi yang luas, situs dan wana wisata puncak damar, pantai cisema, kampung kreatif buricak burinong, budaya serta kesenian lokal yang khas diantaranya seni beluk, tutunggulan dan budaya ngikis.

Keberagaman potensi tersebut menjadi kekuatan dan peluang untuk pengembangan Desa Wisata Pakualam tersebut. Namun pengembangan pariwisata di desa Pakualam belum optimal dalam pemanfaatan produk unggulan sektor pertanian dan perikanan. Komoditas pertanian berupa ubi kayu, pisang, pohon nira(aren), mangga, bambu dan ikan hasil tangkapan dari waduk Jatigede saat ini belum banyak diolah menjadi kuliner dan souvenir yang khas. Menurut hasil penelitian Mardiani dan Hindersah (2017), Desa Paku Alam memiliki kelemahan dalam pengembangan wisatanya diantaranya ketidaksiapan masyarakat pasca penggenangan waduk Jatigede karena tidak memiliki keahlian dan sarana prasarana penunjang wisata di desa Pakualam belum lengkap.

Potensi wisata berupa sumberdaya alam dan budaya lokal yang belum begitu dikenal dan belum terangkat ke permukaan perlu diinventarisasi dan digali melalui industri kreatif menjadi daya tarik wisata yang diharapkan dapat mendukung aktifitas wisata di desa Pakualam. Hal ini, memerlukan suatu pengetahuan dan pemahaman yang baik dan sinergi antara beberapa pihak terkait/stakeholders dalam proses pembuatannya, di mana masyarakat lokal yang lebih banyak berperan karena mereka yang mengetahui secara detail tentang potensipotensi wisata yang mereka miliki

Berdasarkan hasil hasil observasi dan FGD terdapat permasalahan dalam pengembangan desa wisata Pakualam diantaranya: (1) kurangnya pengetahuan dan keterampilan masyarakat dalam memanfaatkan potensi sumberdaya lokal terlihat dari terbatasnya souvenir, produk kuliner dan atraksi wisata, (2) proses produksi dan pengemasan produk kerajinan masih konvensional serta (3) belum tersedianya homestay sebagai salah satu sarana penujang desa wisata. Guna mengatasi permasalahan tersebut perlu dilakukan kegiatan penyuluhan dan sosialisasi industri kreatif dan pendampingan pengelolaan homestay berbasis kearifan lokal.

\section{METODE}

Metodeyang digunakan dalam kegiatan pengabdian pada masyarakat (PPM) di Desa Pakualam berupa penyuluhan dalam bentuk ceramah, diskusi dan tanya jawab serta pendampingan. Adapun tahapan pelaksanaan kegiatan adalah observasi lapangan, penentuan prioritas solusi terhadap permasalahan yang ada, penyusunan materi dan sosialisasi. Kelembagaan masyarakat yang dilibatkan sebagai mitra terdiri dari Kelompok Sadar Wisata, para pengrajin usaha pengolahan pangan yang tergabung dalam KWT mekar arum, Karang taruna dan aparat pemerintahan Desa Pakualam.

Partisipasi masyarakat dalam kegiatan ini adalah sebagai peserta yang terlibat langsung baik sebagai pelaku usaha rumah tangga dan pengelola wisata. Narasumber berasal dari akademisi yaitu dari Fakultas Pertanian danFfakultas Ilmu Sosial politik UNPAD, instansi terkait yaitu Dinas Pariwisata Pemuda dan Olah Raga Kabupaten Sumedang serta praktisi dari pengurus Kompepar Desa Pakualam. Materi yang diberikan dalam kegiatan penyuluhan berupa sosialisasi sadar wisata, pesona wisata, industri kreatif dan Homestay.

\section{HASIL DAN PEMBAHASAN}

\section{Identifikasi Potensi dan Penyuluhan Ekonomi Kreatif Penunjang Atraksi di Desa Wisata Pakualam}

Desa wisata merupakan salah satu bentuk pembangunan pariwisata berbasis masyarakat dan berkelanjutan yang 
perkembangan dan pengelolaanya dikontrol oleh masyarakat lokal, dimana bagian terbesar dari manfaat yang dihasilkan kepariwisataan tersebut dinikmati oleh masyarakat lokal baik yang terlibat secara langsung maupun tidak langsung. Desa wisata diharapkan mampu mengakomodir segala potensi desanya untuk mendukung kegiatan wisata. Hal ini dapat dilakukan melalui industri kreatif.

Pengembangan industri kreatif dapat dilakukan seiring dengan pengembangan dewa wisata karena industri kreatif akan berdampak positif bagi sebuah destinasi wisata. Atraksi wisata dapat menjadi sumber ide-ide keatif yang tidak akan pernah habis untuk dikembangkan. Proses kreativitas seperti pembuatan souvenir dan kuliner dapat menjadi atraksi wisata tersendiri yang memberikan nilai tambah yang khas, menciptakan pasar tersendiri. menyerap tenaga kerja dan sumber pendapatan sebagai salah satu penggerak ekonomi masyarakat desa.

Tabel 1. Potensi Sumberdaya alam dan sosial budaya Desa Pakualam

\begin{tabular}{|c|c|c|}
\hline No & Daya tarik wisata & Keterangan \\
\hline 1 & $\begin{array}{l}\text { Keunikan SDA: } \\
\text { - Keindahan pesisir } \\
\text { pantai dusun Cisema } \\
\text { dan dusun Cilembu } \\
\text { - Keindahan wanawisata } \\
\text { puncak damar } \\
\text { - Memiliki lahan hutan } \\
\text { produksi terbatas } \\
\text { Seluas 91,8 Ha } \\
\text { - Rakit pancing di dusun } \\
\text { Cisema dan Cilembu }\end{array}$ & $\begin{array}{l}\text { Panjang garis pantai dusun } \\
\text { Cisema dan Cilembu sekitar } \\
4 \mathrm{~km} \text {, pantai Cisema dan } \\
\text { Cilembu dikelola secara } \\
\text { swadaya masyarakat, } \\
\text { sedangkan wanawisata puncak } \\
\text { damar dikelola oleh Perum } \\
\text { Perhutani }\end{array}$ \\
\hline 2 & $\begin{array}{l}\text { Keunikan Sosial dan } \\
\text { budaya : } \\
\text { - Wisata Kuliner Nasi Liwet } \\
\text { - Wisata Religi Makom } \\
\text { Kramat situs Puncak } \\
\text { Damar, situs makam astana } \\
\text { gede cilembu,dll } \\
\text { - Taman bacaan masyarakat } \\
\text { (TBM) dusun Cisema } \\
\text { - Budaya ngikis, budaya } \\
\text { ngaruwat bumi } \\
\text { - Seni musik gondang, } \\
\text { beluk, tutunggulan, seni } \\
\text { kuda renggong } \\
\text { - Rintisan Homestay } \\
\text { - Kampung literasi buricak } \\
\text { burinong } \\
\text { - UMKM makanan } \\
\text { ringan (abon dan flake } \\
\text { ikan, flake wortel, flake } \\
\text { bayam, sistik bayam, } \\
\text { sistik wortel, kerupuk } \\
\text { ikan, gantungan kunci, } \\
\text { leuweung, dll) }\end{array}$ & $\begin{array}{l}\text { - Terdapat } 25 \text { warung makan } \\
\text { - Dilakukan festival nasi liwet } \\
\text { setiap tahun } \\
\text { - Banyak dikunjungi peziarah } \\
\text { di bulan Maulid Nabi } \\
\text { - Tempat belajar masyarakat } \\
\text { dusun Cisema } \\
\text { - Dilakukan 1x per tahun } \\
\text { bulan Maulid } \\
\text { - Pertunjukan saat acara masal } \\
\text { desa } \\
\text { - Terdapat } 10 \text { rumah yang } \\
\text { dipersiapkan menjadi } \\
\text { homestay } \\
\text { - Terdapat } 4 \text { Kelompok } \\
\text { Wanita Tani yang melakukan } \\
\text { usaha pengolahan pangan } \\
\text { lokal }\end{array}$ \\
\hline
\end{tabular}

Sumber : hasil observasi, FGD dan monografi Desa Pakualam

Pada kegiatan ini teridentifikasi beberapa hasil industri kreatif yang sudah ada di desa Pakualam dalam bidang kuliner terdapat nasi liwet, ikan asin dan abon ikan lalawak, flake dan sistik sayuran, flake dan sistik ikan, kerupuk ikan, leumeung sampeu, dan asinan buah-buahan.
Di bidang sosial dan budaya terdapat kampung calakan buricak burinong beserta taman bacaan masyarakat (TBM) Maharani dan Kelompok belajar Motekar, upacara ngikis dan seren taun. Setiap tahun di desa Pakualam sudah diagendakan festival nasi liwet untuk promosi wiata dan memotivasi warga dalam berkreasi di bidang kuliner

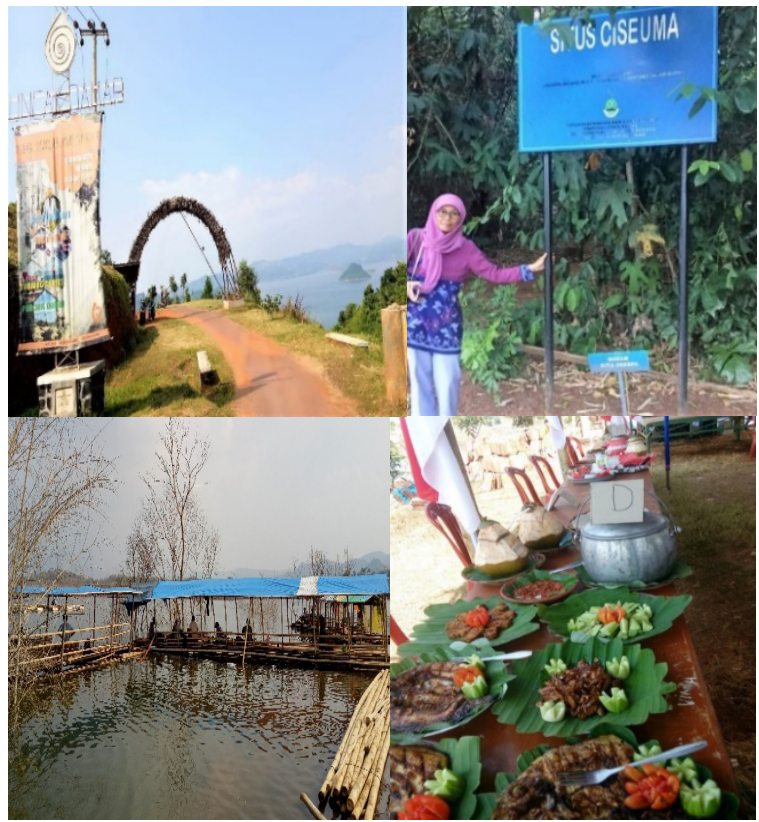

Gambar 1. Potensi Alam dan Sosial Budaya Desa Pakualam Kecamatan Darmaraja Sumedang

Guna mengembangkan ekonomi kreatif, diperlukan sumberdaya manusia berkualitas dengan daya inovasi dan kreativitas yang tinggi serta wadah sebagai tempat penggalian ide, berkarya, sekaligus aktualisasi diri dan ide-ide kreatif. Berdasarkan data potensi sumberdaya alam dan sumberdaya manusia Desa Pakualam, pengembangan aktifitas ke arah industri kreatif harus segera di lakukan untuk menunjang desa wisata.

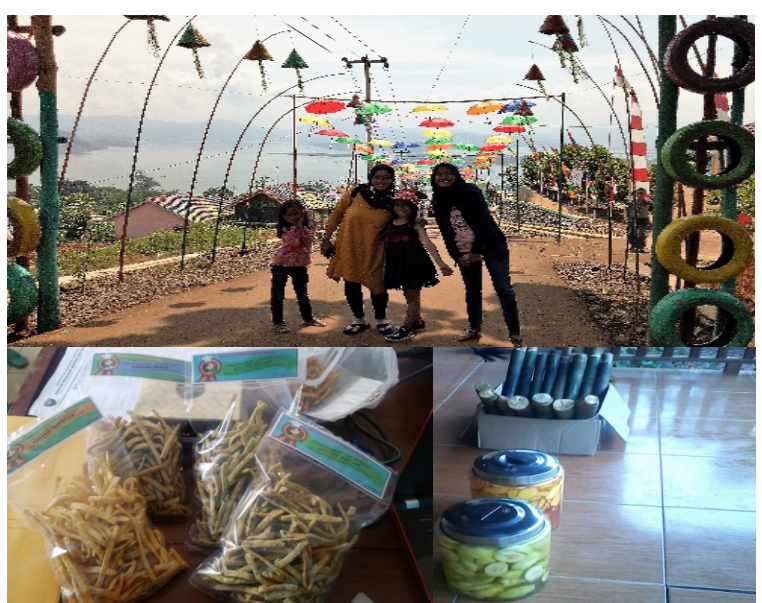

Gambar 2. Produk Kreatif Desa Pakualam Kampung Calakan Buricak Burinong dan Kuliner

Penyuluhan industri kreatif berlangsung pada hari Sabtu tanggal 14 Juli 2018 berlokasi di balai desa Paku alam dan dihadiri oleh sejumlah peserta yang berasal dari kalangan tokoh masyarakat, anggota kelompok wanita tani Mekar Arum, anggota Karangtaruna, pemuda desa, pengelola 
wisata pantai Cisema dan aparat desa pakualam. Materi yang disampaikan berupa motivasi dan pengetahuan mengenai pemanfaatan sumberdaya lokal menjadi produk kreatif yang bernilai ekonomi sebagai contoh mengolah potensi aren menjadi gula aren dan gula semut dengan bentuk yang menarik, mengolah pisang menjadi keripik pisang yang renyah, handycraf dari barang bekas(kertas/ kayu/pastik), membuat topi dari bahan bambu bertuliskan Desa pakualam dan membuat sandal jepit bertuliskan kampung calakan buricak burinong sebagai souvenir untuk dijual kepada wisatawan yang berkujung ke Pakualam.

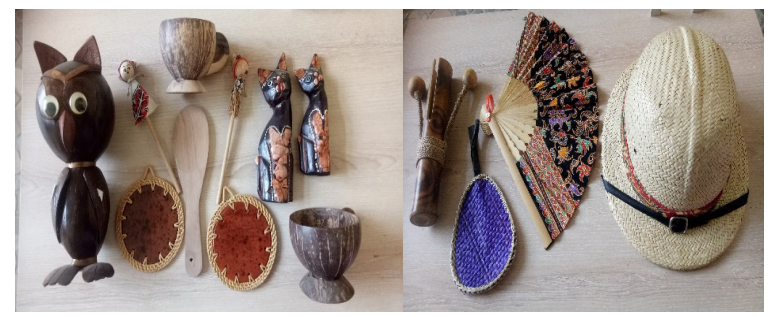

Gambar 3. Produk industri kreatif untuk penunjang desa wisata Pakualam

Secara umum kendala yang dihadapi oleh warga Desa Pakualam dalam mengembangkan industri kreatif adalah permodalan, keterampilan SDM, teknologi produksi, pemasaran dan dukungan pemerintah.

Industri kreatif yang baerada di desa pakualam termasuk kelompok usaha rumah tangga dengan profil usaha dikelola oleh 1s.d 4 orang pekerja, modal yang terbatas kurang dari 20 juta dan belum menerapkan pembukuan usaha. Sumberdaya manusia pelaku industri kreatif memiliki keahlian terbatas dan tidak memiliki pembagian kerja dalam manajemen produksinya. Akses pasar produk industri kreatif ini juga terbatas hanya di sekitar obyek wisata yang berada di desa Pakualam sehingga sulit berkembang.

\section{Sosialisasi dan Penyuluhan Homestay Guna Men- dukung Desa Wisata}

Kegiatan pariwisata tidak terlepas dari kebudayaan atau kehidupan masyarakat. Oleh karena itu, dalam kegiatan pariwisata akan terjadi interaksi budaya antara wisatawan dan masyarakat lokal. Kegiatan keseharian masyarakat dalam aktifitas pertanian, perkebunan, peternakan dan perikanan bisa menjadi atraksi wisata yang menarik.

Guna mendukung Pakualam sebagai desa wisata yang menerapkan konsep low cost turism (LCT), maka perlu menciptakan attraction, access dan acomodation (3A) yang terjangkau oleh masyarakat luas dengan memanfaatkan potensi yang ada. Desa Pakualam harus menyediakan homestay (pondok wisata) agar wisatawan yang datang dapat berinteraksi dengan masyarakat, belajar mengenai budaya dan kehidupan setempat. Homestay dapat diartikan sebagai rumah tinggal yang sebagian kamarnya disewakan kepada tamu dalam jangka waktu tertentu untuk memperlajari budaya setempat atau suatu rutinitas tertentu.
Pada awalnya pengembangan homestay secara sukarela dari keluarga yang mau memberi tumpangan wisatawan yang ingin menginap di Desa Pakualam.. Homestay sangat cocok dikembangkan di desa wisata Pakualam yang mengusung konsep pemberdayaan masyarakat karena dikelola secara mandiri oleh warga, biaya yang terjangkau dan memungkinkan adanya interaksi pengunjung dengan warga layaknya keluarga sendiri sehingga memberikan kesempatan pengunjung untuk berinteraksi dengan masyarakat lokal secara intens.

Saat ini wisatawan yang akan bermalam di Desa Pakualam masih jarang dan tidak dalam jumlah besar. Kondisi ini kurang mendukung bagi pengembangan desa wisata. Hal ini juga berdampak pada sedikitnya pengunjung yang memanfaatkan jasa homestay, kecuali kelompok tertentu yang sedang menggunakan Desa Wisata Pakualam untuk acara tertentu seperti penelitian, kunjungan kerja atau kegiatan off road.

Homestay yang memadai dalam suatu desa wisata bermakna rapi, bersih, memiliki kamar mandi yang sehat dan pemilik rumah yang ramah terhadap pengunjung. Berdasarkan hasil penelitian Aminudin (2015) terdapat tiga hal yang harus diperhatikan dalam pengelolaan homestay yaitu kebersihan, kenyamanan dan keamanan. Salah satu kendala dalam pengelolaan homestay adalah tidak adanya sosialisasi atau pelatihan yang diberikan untuk masyarakat, sehingga masyarakat tidak bisa menyewakan rumah mereka untuk wisatawan yang melakukan kegiatan wisata.

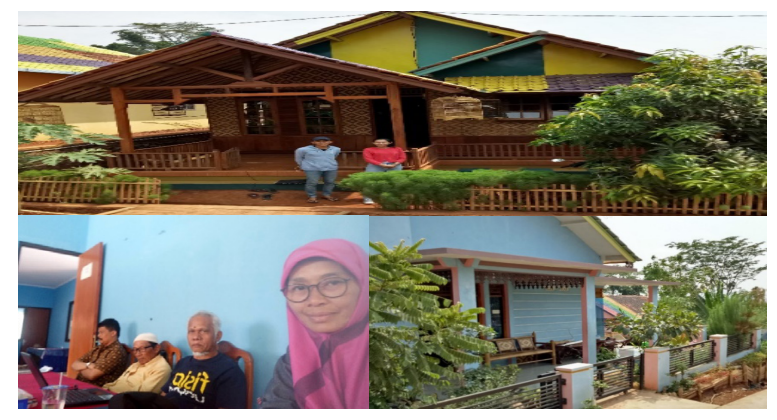

Gambar 4. Penyuluhan dan Observasi Homestay di Desa Pakualam

Sosialisasi dan penyuluhan homestay di desa Pakualam dilaksanakan pada hari Sabtu tanggal 19 Oktober 2018, bertempat di balai desa dan dihadiri oleh tokoh masyarakat, aparat desa, ketua karang tauna dan kompepar desa Pakualam. Selain sosialisasi dan motivasi dalam pengelolaan homestay, pada kegiatan ini dilakukan pendataan terhadap 10 rumah warga yang akan dijadikan homestay. Selanjutnya dilakukan kunjungan dan pendampingan kepada pemilik rumah tersebut dalam menyediakan homestay yang bersih, nyaman dan aman.

Namun berdasarkan hasil observasi dan wawancara langsung dengan pemilik rumah ternyata diketemukan beberapa kendala dalam penyediaan homestay diantaranya: (1) kekurangan ruangan, tidak ada kamar yang khusus hanya memanfaatkan kamar yang tidak digunakan oleh anggota keluarga karena sedang bersekolah atau bekerja 
di luar kota, (2) bergabungnya kamar mandi pemilik homestay dengan wisatawan (3) Fasilitas pendukung (tempat sampah, tempat tidur, lemari, meja dan kursi) tidak lengkap, serta (4) kurangnya pemahaman dan keterampilan dalam pengelolaan homestay.

Faktor pendorong keberhasilan penyuluhan industri kreatif dan homestay adalah terdapatnya dukungan dari aparat desa dan partisipasi aktif warga masyarakat Desa Pakualam. Saat ini pemerintah desa Pakualam sedang giat membangun desa wisata guna menjadi sumber penghasilan bagi orang terkena dampak (OTD) waduk Jatigede. Motivasi bertahan hidup pasca pengenangan waduk Jatigede mendorong masyarakat Desa Pakualam untuk lebih kreatif dalam memanfaatkan potensi dan peluang yang ada sejalan berkembangnya wisata di kawasan waduk Jatigede. Sedangkan faktor teknis penghambat dari kegiatan PPM adalah lokasi antar dusun yang saling berjauhan bahkan ada yang terhalang genangan wasuk Jatigede sehingga tidak semua warga desa terjangkau oleh kegiatan PPM.

\section{SIMPULAN}

Program PPM yang ditujukan kepada masyarakat desa Pakualam melalui kegiatan penyuluhan industri kreatifdan sosialisasi homestay sebagai upaya untuk meningkatnya pengetahuan dan kesadaran warga masyarakat dalam memanfaatkan potensi sumberdaya alam, sosial dan budaya lokal menjadi produk penunjang daya tarik wisata. Kendala utama dalam pengembangan industri kreatif di desa wisata Pakualam adalah permodalan, keterampilan SDM, teknologi produksi, pemasaran dan dukungan pemerintah. Sedangkan kendala dalam penyediaan homestay adalah kekurangan ruangan, fasilitas pendukung (kamar mandi, tempat sampah, tempat tidur, dll) yang tidak lengkap, serta kurangnya pemahaman dan keterampilan dalam pengelolaan homestay. Faktor pendorong keberhasilan industri kreatif dan homestay adalah terdapatnya dukungan dari aparat desa, partisipasi aktif warga masyarakat yang dilatar belakangi oleh motivasi kuat untuk bertahan hidup pasca pengenangan waduk Jatigede serta terdapat peluang semakin berkembangnya wisata di kawasan waduk Jatigede.

\section{UCAPAN TERIMAKASIH}

Ucapan tereimakasih penulis sampaikan kepada Dekan Fakultas Pertanian dan Direktur Riset Pengabdian kepada Masyarakat dan Inovasi Unpad yang telah mendukung kegiatan PKM ini melalui dana Hibah internal Unpad tahun 2018.

\section{DAFTAR PUSTAKA}

Aminudin A.R, (2015). Pelaksanaan Pengelolaan Homestay di desa Lubuk Kembang Bunga Kawasan Ekowisata Tesso Nilo Kabupaten Pelalawan Provinsi Riau. Jurnal online mahasiswa FISIP Universitas Riau. Vol. 2 No. 2. pp 1-13 https://jom.unri.ac.id/index.php/JOMFSIP/article/ view/6981/6668

Djuwendah E, Hapsari, H., Deliana, Y., \& Suartapradja, O. S. (2017). Potensi Ekowisata Berbasis Sumberdaya Lokal di Kawasan Waduk Jatigede Kabupaten Sumedang. Jurnal Paspalum UNWIM ISSN 2088-5113, Vol. 5 No. 2.pp 153-163.

Hadiwijoyo, Suryo Sakti. (2018). Perencanaan Pengembangan Desa Wisata Berbasis Masyarakat Yogyakarta: Suluh Media pp 35-38

Mardiani, N dan Hindersah H. (2017). Strategi Pengembangan Ekowisata waduk Jatigede di Desa Pakualam Kecamatan Darmaraja Sumedang. Proceding Perencanaan Wilayah dan Kota. SPESIA UNISBA. ISSN 2460-6480. Vol 3 No 1 pp 118-125.

Nuryanti, Wiendu. (1993) Concept, Perspective, and Challenges: Laporan Konferensi Internasional mengenai Pariwisata budaya. Yogyakarta: Gadjah Mada University Press

Simatupang T, dkk (2009).Analisis Kebijakan Pengembangan Industri Kreatif di Kota Bandung Jurnal Teknologi Manajemen, ITB . ISSN 14121700 hal 1-12. vol 8 No 1 , 